\title{
Article
}

\section{Mycophenolate mofetil for induction of remission in Crohn's disease}

Gordon, Morris, Thomas, Adrian G and Akobeng, Anthony K

Available at https://clok.uclan.ac.uk/28783/

Gordon, Morris orcid iconORCID: 0000-0002-1216-5158, Thomas, Adrian G and Akobeng, Anthony K (2019) Mycophenolate mofetil for induction of remission in Crohn's disease. Cochrane Database of Systematic Reviews .

It is advisable to refer to the publisher's version if you intend to cite from the work. http://dx.doi.org/10.1002/14651858.cd009123.pub2

For more information about UCLan's research in this area go to

http://www.uclan.ac.uk/researchgroups/ and search for <name of research Group>.

For information about Research generally at UCLan please go to http://www.uclan.ac.uk/research/

All outputs in CLoK are protected by Intellectual Property Rights law, including Copyright law. Copyright, IPR and Moral Rights for the works on this site are retained by the individual authors and/or other copyright owners. Terms and conditions for use of this material are defined in the policies page.

\section{CLoK}

Central Lancashire online Knowledge www.clok.uclan.ac.uk

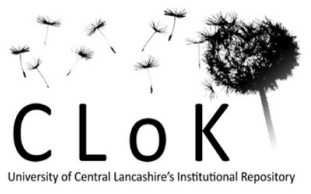




\section{(E) Cochrane Library}

Cochrane Database of Systematic Reviews

\section{Mycophenolate mofetil for induction of remission in Crohn's disease (Protocol)}

Gordon M, Thomas AG, Akobeng AK

Gordon M, Thomas AG, Akobeng AK.

Mycophenolate mofetil for induction of remission in Crohn's disease.

Cochrane Database of Systematic Reviews 2019, Issue 6. Art. No.: CD009123.

DOI: 10.1002/14651858.CD009123.pub2.

www.cochranelibrary.com 
TABLE OF CONTENTS

HEADER . . . . . . . . . . . . . . . . . . . . . . . . . . . . . . . . . . . . . . . . 1

REASON FOR WITHDRAWAL . . . . . . . . . . . . . . . . . . . . . . . . . . . . . . . . . . . . . .

WHAT'S NEW . . . . . . . . . . . . . . . . . . . . . . . . . . . . . . . . . . . . . . . . . . . . . . . 1

Mycophenolate mofetil for induction of remission in Crohn's disease (Protocol)

Copyright $\odot 2019$ The Cochrane Collaboration. Published by John Wiley \& Sons, Ltd. 
[Intervention Protocol]

\title{
Mycophenolate mofetil for induction of remission in Crohn's disease
}

\author{
Morris Gordon ${ }^{1,2}$, Adrian G Thomas ${ }^{3}$, Anthony K Akobeng ${ }^{4}$ \\ ${ }^{1}$ School of Medicine, University of Central Lancashire, Preston, UK. ${ }^{2}$ Families Division, Blackpool Victoria Hospital, Blackpool, UK. \\ ${ }^{3}$ Royal Manchester Children's Hospital, Manchester, UK. ${ }^{4}$ Sidra Medicine, Doha, Qatar \\ Contact address: Anthony K Akobeng, Sidra Medicine, PO Box 26999, Doha, Qatar. aakobeng@sidra.org, akobeng@aol.com.
}

Editorial group: Cochrane IBD Group.

Publication status and date: Withdrawn from publication for reasons stated in the review, published in Issue 6, 2019.

Citation: Gordon M, Thomas AG, Akobeng AK. Mycophenolate mofetil for induction of remission in Crohn's disease. Cochrane Database of Systematic Reviews 2019, Issue 6. Art. No.: CD009123. DOI: 10.1002/14651858.CD009123.pub2.

Copyright (C) 2019 The Cochrane Collaboration. Published by John Wiley \& Sons, Ltd.

The editorial group responsible for this previously published document have withdrawn it from publication.

\section{REASON FOR WITHDRAWAL}

This protocol is being withdrawn because it is out of date.

WHAT'S NEW

Date Event Description

4 June 2019 Amended This protocol is being withdrawn 